\title{
Juridical Study of Premarital on Joint Property which Made by Notary and Legal Consequences in The District of Kudus
}

\author{
Pulung Jati Kusuma ${ }^{1}$ and Akhmad Khisni
}

Abstract. Premarital agreements on joint property made before or during the marriage took place, the parties may determine the contents of the agreement, especially respect the innate property of each party in a premarital agreement. In Act No. 1 of 1974 About the Marriage of Article 29 paragraph (1) confirms that at the time or before the marriage took place two parties by mutual consent may submit a written agreement authorized by the employee registrar of marriage, after which it shall also apply to third parties lodged. Having made premarital agreement then the next must be registered in the district court clerk's office in legal marriages were held, the purpose of such registration in order to satisfy the principle of publicity. Background of the problem, authors conducted a study entitled "Juridical Study Of Premarital On Joint Property Which Made By Notary And Legal Consequences In The District Of Kudus". This study raises the issue of implementation of joint property on premarital agreement made by the notary in Kudus and the legal consequences of the implementation of a premarital agreement. The purpose of this study is to investigate the implementation of the agreement For Premarital of joint property made by a notary in Kudus and to know the legal consequences of a premarital agreement made by the notary. The data used in this study are primary data, secondary data and data that can support tertiary study, which was then analyzed by descriptive analysis method. Based on the results of data analysis concluded that Premarital agreements about the estate property that is made before a notary in the Kudus District by husband and wife time before or after the course of the marriage as provided for in Article 29 of Act No. 1 of 1974 About Marriage asserts that the agreement must not violate limits of the law, religion and morality. Agreement it means the contents can be related to any of any one of them the separation of joint property during the agreement was detrimental to the parties and does not conflict with the nature and purpose of marriage. The legal consequences premarital agreement made by a notary it is binding and valid as the Law for the parties. If the premarital agreement that has been made by the husband and wife there was a violation.

Keywords: Juridical Study; Premarital Agreements; Joint Property.

\section{Introduction}

Marriage is one of the means to keep people from sin. In Islam many Quranic verses that advise Muslims to do the wedding, one of them the word of God in the Qur'an. An-Nur (24): 32, namely:

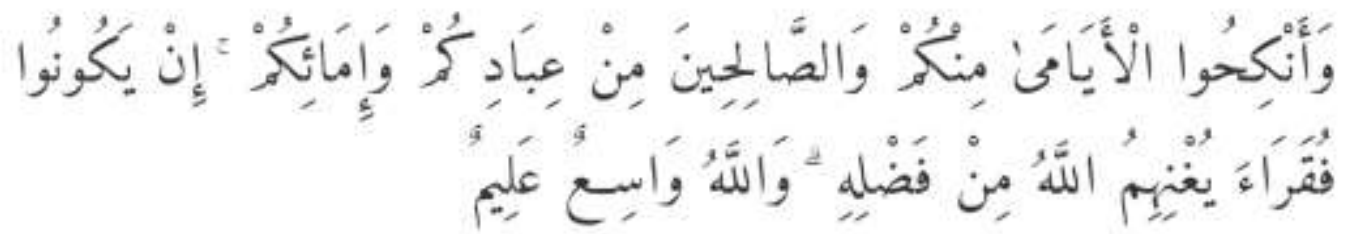

It means: "And marry people who are still single among you, and also the people who deserve (get married) and your servants male or female. If they are poor, God will provide the ability for them with His grace and Allah is the Widest (his gift), and He is the

\footnotetext{
${ }^{1}$ Student of Master Program (S2) of Notaries Faculty of Law UNISSULA Semarang email pulung.jati01@gmail.com

${ }^{2}$ Lecturer in Faculty of Law UNISSULA Semarang
} 


\section{Knowest."}

Definition of marriage under Article 1 of Act No. 1 Of 1974 About Marriage, which reads both inner and outer bond between a man and a woman as husband and wife with the purpose of forming a family (household) who are happy and everlasting based on God.

According to Islamic law is a marriage is a contract that justifies the association and restrict the rights and obligations and mutual help between a man and a woman who previously between the two are not unrelated. ${ }^{3}$ Under these provisions then the marriage is composed of five elements, namely: Bonding the inner and outer; Between a man and a woman; As husband and wife; Forming families (households) are happy and eternal; Based on God

While the course of a marriage that while it is also the emergence of rights and obligations between husband and wife on a reciprocal basis. However, in practice, to build a happy family, lasting relationships, and nurtured by the struggle to be cluttered with useless because of the disruption of marriage.

Disconnect marriage is the bond of marriage between a man and a woman is over. Divorce in Islamic law is something that principle lawful act forbidden by God. The breakdown of marriage means also the end of the marital relationship. The breakdown in the marriage depends on the terms of who is willing to break the marriage. According to Islamic law in this case there are four (4) possibilities:

- The breakdown of marriage on the will of God through death.

- The breakdown of marriage on the husband's will called divorce.

- The breakdown of marriage on the wife's will called khulu'"

- The breakdown of marriage at the discretion of the judge as a third party called fasakh. ${ }^{4}$

To keep all the bad possibilities and is also used as a means to minimize the occurrence of a divorce is going to happen, not a few couples who marry to make an agreement commonly called the covenant of marriage.

Understanding of the agreement to marry is an agreement made at or before the holding of wedding and binding on both the bride who is getting married, the general contents of the agreement mating namely on the issue of distribution of wealth (Gono-gini) between husband and wife which includes what belongs to the husband or wife, what are the responsibilities of the husband and wife, or related to the innate property of each party in order to discern where the property where the wife and the husband's property, in the event of divorce or death in one pair.

The marriage contract can be regarded as a written agreement between the prospective husband and bride getting married on the property and binding during their marriage and the consequences of the end of their marriage that deviate from the principle or the pattern set by law. ${ }^{5}$ Not a few couples who will carry out the marriage makes marriage agreement or commonly called a premarital agreement. The agreement was made to maintain professionalism, relationships and their image, also avoid charges of one of the parties just want to get a wealth of other parties, especially on the division of common property or joint property. Mating agreement has been chosen by the top that has a great heritage, in the absence of a premarital agreement then the property of husband and wife to be a treasure of unity round.

If seen the agreement in the Act No. 1 of 1974 on Marriage, that the marriage covenant

\footnotetext{
${ }^{3}$ H. Sulaiman Rasyid in Sudarsono 2005 Hukum Perkawinan Nasional.

${ }^{4}$ Amir Syarifuddin 2006 Hukum Perkawinan Islam di Indonesia Kencana Jakarta p.917.

5 R. Sotojo Prawirohamidjojo and Asis Safioedin 1980 Hukum Orang dan Keluarga Alumni Bandung p.57.
} 
aims to affirmation of settings and problems of marital property between husband and wife. Islamic law in the new marriage contract is valid if made before or at the time of the marriage in accordance with the provisions of Article 47 paragraph (1) Compilation of Islamic Law.

Mating agreement is part of the covenant law bound. Article 1320 of the Civil Code has set the terms validity of the agreement are: They agreed that bind him; Ability to make a deal; Any particular case; And a cause that kosher

Premarital agreements are typically made to order to solve the problem on a few issues that usually arise after the marriage through divorce. That the problem is usually the fate of the innate property and division of joint property between husband and wife is the former. Actually the default property and joint property after divorce has been regulated in Article 35 and Article 37 of the Marriage Act. If husband and wife have an agreement, then the default property and joint property after divorce will be governed in accordance with the agreed terms and formulated.

Premarital made, done either in writing or deed, either under the arm or in an authentic deed made by a competent authority. What is meant by deed is a letter by a signature, which includes all the events that form the basis of a right or engagement, and built in the first intentionally to proof. ${ }^{6}$

In connection with the authentic deed, the notary is a public official authorized to make an authentic deed. Judging from the article 1, paragraph 1 of Act No. 30 of 2004 About Notary reads the notary is a public official authorized to make an authentic deed and have more authority as referred to in this Act or under the Act other. And paragraph 7 states hereinafter referred to as the notarial deed is a deed authentic deed made by or before a notary in the form and manner set forth in this Act.

From the description above, the writer will do research with the title of the thesis is: " Juridical Study Of Premarital On Joint Property Which Made By Notary And Legal Consequences In The District Of Kudus".

\section{Research methods}

In this study the authors used socio-juridical method. Juridical is an approach that uses the principles and legal principles derived from the rule-writing, while sociological peratutran is an approach that aims to clarify, in other words giving importance to the steps of observation. ${ }^{7}$ Means a juridical sociological research not only in addition to using the principles and the principles of the law but directly involved in reviewing, view and analyze the problems, and how its implementation in practice.

Research specifications is descriptive analysis, which describes the problem and then analyze the existing problems through data that has been collected, processed, and prepared based on the theories used. This study is expected to obtain a clear picture of understanding, a detailed and systematic way of analyzing data to solve the problem in accordance with the provisions of applicable law.

Primary legal materials is data obtained directly from the field / community, observation and direct interviews were conducted with relevant parties.

Material is a secondary data collection methods that made indirectly through literature study ways to search for concepts, theories, legal expert's opinion, the legislation relating to the problems of research in the form of: Materials Primary Law, which is derived from

\footnotetext{
${ }^{6}$ Soedikno Mertokusumo 1996 Hukum Acara Perdata di Indonesia Liberty Yogyakarta p.106.

7 Ronny Hanitijo Soemantri 1995 Metodologi Penelitian Hukum dan Jurimetri Ghalia Indonesia Jakarta p.14.
} 
the legislation include: Code of Civil law; Act No. 30 Of 2004 on Notary; Act No. 2 of 2014 on the Amendment of Act No. 30 Of 2004 on Notary; Act No. 1 of 1974 About Marriage; Compilation of Islamic Law. Secondary Legal Materials, namely the literature-text explaining the primary legal data which includes scientific books on law, books of reference, the work of the legal experts, as well as the study of the documents relating to the cases. Tertiary Legal Materials, is a legal substance that supports the primary legal materials and secondary law by giving understanding and understanding of other legal materials. ${ }^{8}$

This method is the latest stage in a research activity. The meaning of the data analysis process of data collection which is based on all the data that has been processed and obtained from secondary data in the form of primary legal materials, secondary law, and tertiary legal materials. And supported on primary data obtained through interviews of the informant. In this study, data analysis method used is qualitative analysis, the process of analysis of quantitative data obtained from the field, which is a result of interviews conducted with respondents. ${ }^{9}$

The data has been collected, studied, and analyzed based on the facts of a general nature subsequently drawn conclusions that are special to reach the answers to the issues discussed. Data obtained either in writing or verbally is what is expected to be able to obtain a clear picture of the underlying problems and can be used to draw conclusions in this study.

\section{Results and Discussion}

\subsection{Premarital On Joint Property Which Made By Notary And Legal Consequences In The District Of Kudus}

Said a premarital agreement as a written agreement between the prospective husband and wife candidates that will be or have been married on the property and binding during their marriage and the consequences of the end of their marriage that deviate from the principle or pattern set Act. agreements manufacture premarital agreement provided that the content of the agreement does not violate the limits of the law, moral values, religion and morality. Article 29 paragraph 1 of Act No. 1 of 1974 About Marriage says "At the time of or before the marriage took place, the two parties by mutual consent may submit a written agreement authorized by the employee registrar marriage after which it shall also apply to third parties throughout the third party lodged ".

Notary is a competent authority in making authentic deed one premarital. This was stated in Article 1, paragraph 1 of Act No. 2 Of 2014 On Notary namely: "The notary is a public official who is authorized to make authentic deeds and other authorities referred to in this Act." Premarital agreements made by the notary load all things desired by the husband and wife in the form of rights and obligations of the parties during the marriage and prohibitions which must not be violated.

Premarital agreements must be made by notarial deed, if a married agreement is not made by notarial deed then the mating agreement null and void. In Article 29, the UUP, on or before the marriage took place two parties by mutual consent can file a written agreement approved by the marriage registrar employee, after which it shall also apply to third parties lodged. According to the provisions of Article 29 Paragraph 1 of the Marriage Law, marriage agreement endorsed by the Marriage Registrar Officer. According to the

\footnotetext{
8 Peter Mahmud Marzuki 2009 Penelitian Hukum Kencana Prenada Media Group Jakarta p.93.

${ }^{9}$ Ibid p. 54.
} 
"authorized" in the sentence means is that the marital agreement should be "recorded" and when the marriage covenant are not recorded then the marriage contract is not binding on third parties.

The provisions of Article 29 Paragraph 4 which states that "the marriage contract in effect since marriage is taking place" it can be concluded that the mating agreement and ratification by employees marriage registrar should be conducted prior consent of Kabul between the bride and groom. ${ }^{10}$

Registration of marriage agreement after the entry into force of the UUP is no longer practiced in the District Court Clerk's Office but conducted by the Marriage Registration Officer at the Civil Registry Office (Office of Population and Civil) or the Office of Religious Affairs.

Act of ratification by the employee is merely to legitimize agreement involves mating with the registrar of marriage as a representative of the institution of marriage registrar. The purpose of the notarial deed is authentic deed, not the deed under hand. An authentic deed is a deed made by or before the competent authority (Notary). The requirement that the agreement must be made with the mating notarial deed is intended order for the mating agreements have perfect strength of evidence in case of disputes. An agreement as outlined in an authentic deed, it will have the strength of evidence is perfect. And with the establishment of mating in notarial agreement will provide legal certainty about the rights and duties of husband and wife on their property, ${ }^{11}$

\subsection{As a result of Premarital Agreements Law On Joint property Made By Notary}

We make a premarital agreement then the parties do not want to mixing property and profit and loss. Thus the marital assets remain the property of their respective hence their results both during the marriage of business and personal assets will remain the property of their respective by the parties

The legal consequences premarital agreement made by a notary it is binding and valid as the Law for the parties. If a premarital agreement that has been made by the husband and wife there is a violation, then automatically entitles the wife to ask for cancellation or as a reason for divorce is, as already mentioned in Article 51 Compilation of Islamic Law, which reads: "The violation of the marriage covenant entitles wife to request cancellation of marriage or present it as a reason for divorce is the Religious Court ".

When one party does not do as the contractual agreement and the consequences loss the other party, then the party who feels aggrieved can claim their right to trial. Article 51 Compilation of Islamic Law asserts that the violation of the marriage covenant entitles the wife to ask for the cancellation of marriage or file a lawsuit as a reason for the Religious Courts. However, if the demand for compensation when pure breach of a treaty by one of the parties it can be submitted to the District Court to seek redress on agreements are not implemented or not met.

\section{Closing}

\subsection{Conclusion}

- Premarital agreements must be made by notarial deed, if a married agreement is not made by notarial deed then the mating agreement null and void. In Article 29, the UUP, on or before the marriage took place two parties by mutual consent can file a written

\footnotetext{
${ }^{10}$ Andy Hartanto 2012 Hukum Harta Kekayaan Perkawinan Laksbang Grafika Yogyakarta p.3.

${ }^{11}$ Ibid p.34.
} 
agreement approved by the marriage registrar employee, after which it shall also apply to third parties lodged. According to the provisions of Article 29 Paragraph 1 of the Marriage Law, marriage agreement endorsed by the Marriage Registrar Officer. According to the "authorized" in the sentence means is that the marital agreement should be "recorded" and when the marriage covenant are not recorded then the marriage contract is not binding on third parties. The provisions of Article 29 paragraph (4) of Act No. 1 of 1974 About the marriage which states that "the marriage contract in effect since marriage is taking place" it can be concluded that the creation and ratification of a premarital agreement by employees marriage registrar should be conducted prior consent of Kabul between the bride and groom, Recording premarital done by the Marriage Registration Officer at the Civil Registry Office (Office of Population and Civil) or the Office of Religious Affairs. Act of ratification by the employee is merely to legitimize agreement involves mating with the registrar of marriage as a representative of the institution of marriage registrar.

- The legal consequences premarital agreement made by a notary it is binding and valid as the Law for the parties. If a premarital agreement that has been made by the husband and wife there is a violation, then automatically entitles the wife to ask for cancellation or as a reason for divorce is, as already mentioned in Article 51 Compilation of Islamic Law, which reads: "The violation of the marriage covenant entitles wife to request cancellation of marriage or present it as a reason for divorce is the Religious Court".

\subsection{Suggestion}

- The first suggestion is addressed to candidates or the couple that will make the couple's marriage covenant should know in detail all matters relating to the marriage contract from the shape, conditions and legal consequences arising in the presence of the marriage covenant.

- The second suggestion is addressed to the notary in order to provide counseling or referral to the positive sides or the purpose and benefits of making the marriage contract that is as protector of rights and provide awareness of the rights and obligations of each party as well as protect from abuse in the household,

\section{Bibliography}

[1] Al-Qur'an

[2] Amir Syarifuddin, 2006, Hukum Perkawinan Islam di Indonesia, Kencana, Jakarta.

[3] Andy Hartanto, 2012, Hukum Harta Kekayaan Perkawinan, Laksbang Grafika, Yogyakarta.

[4] H. Sulaiman Rasyid in Sudarsono, 2005, Hukum Perkawinan Nasional.

[5] Peter Mahmud Marzuki, 2009, Penelitian Hukum, Kencana Prenada Media Group, Jakarta.

[6] R. Sotojo Prawirohamidjojo and Asis Safioedin, 1980, Hukum Orang dan Keluarga, Alumni, Bandung.

[7] Soedikno Mertokusumo, 1996, Hukum Acara Perdata di Indonesia, Liberty, Yogyakarta.

[8] Law of the Republic of Indonesia Number 30 Of 2004 concerning Notary

[9] Law of the Republic of Indonesia Number 2 of 2014 on the Amendment of Act No. 30 of 2004 concerning Notary

[10] Law of the Republic of Indonesia Number 1 Of 1974 About Marriage

[11] Presidential Instruction No. 1 of 1991 on the Compilation of Islamic Law 